\title{
Primary Bioassay of Human Myeloma Stem Cells
}

\author{
ANNE HAMBurger and SydNEy E. SALMON, Section of Hematology \\ and Oncology, Department of Internal Medicine, and The Cancer \\ Center, University of Arizona College of Medicine, Tucson, \\ Arizona 85724
}

A B STRACT The ability to clone primary tumors in soft agar has proven useful in the study of the kinetics and biological properties of tumor stem cells. We report the development of an in vitro assay which permits formation of colonies of human monoclonal plasma cells in soft agar. Colony growth has been observed from bone marrow aspirates from $75 \%$ of the 70 patients with multiple myeloma or related monoclonal disorders studied. Growth was induced with either $0.02 \mathrm{ml}$ of human type $\mathrm{O}$ erythrocytes or $0.25 \mathrm{ml}$ of medium conditioned by the adherent spleen cells of mineral oil-primed $\mathrm{BALB} / \mathrm{c}$ mice. 5-500 colonies appeared after 2-3 wk in culture yielding a plating efficiency of $0.001-0.1 \%$. The number of myeloma colonies was proportional to the number of cells plated between concentrations of $10^{5}-10^{6}$ and back-extrapolated through zero, suggesting that colonies were clones derived from single myeloma stem cells. Morphological, histochemical, and functional criteria showed the colonies to consist of immature plasmablasts and mature plasma cells. $60-80 \%$ of cells picked from colonies contained intracytoplasmic monoclonal immunoglobulin. Colony growth was most easily achieved from the bone marrow cells of untreated patients or those in relapse. Only $50 \%$ of bone marrow samples from patients in remission were successfully cultured. Tritiated thymidine suicide studies provided evidence that for most myeloma patients, a very high proportion of myeloma colony-forming cells was actively in transit through the cell cycle. Velocity sedimentation at $1 \mathrm{~g}$ showed myeloma stem cells sedimented in a broad band with a peak at $13 \mathrm{~mm} / \mathrm{h}$. Antibody to granulocyte colony-stimulating factor did not reduce the number or size of the colonies. Increased numbers of myeloma colonies were seen when the marrow was depleted of colony-stimulating

This work was presented in part at the Annual Meeting of the American Society of Hematology held December 1976 in Boston, Mass.

Received for publication 14 March 1977 and in revised form 6 June 1977. factor elaborating adherent cells before plating. This bioassay should prove useful in studying the in vitro biological behavior of certain bone marrowderived (B)-cell neoplasia. In addition, systematic and predictive studies of anticancer drug effects on myeloma stem cells should now be feasible.

\section{INTRODUCTION}

Multiple myeloma has served as a valuable model neoplasm in both mouse and man (1). Studies of myeloma immunoglobulin (M-component) synthesis and metabolism have been applied to quantitate the total body number of myeloma cells and to follow changes in tumor mass with treatment. Such serial tumor kinetic studies, and those of the tritiated thymidine labeling index of the tumor, have provided important insights on the kinetics of growth and regression of myeloma and on approaches to treatment $(1,2)$. However, such studies do not directly assess the key compartment of the tumor, the tumor stem cells. Tumor stem cells provide the basic cell renewal system of the tumor, and are necessary to provide the colonizing property of a neoplasm capable of metastasis.

Usually, tumor stem cells have been assessed functionally in animals with various in vivo transplantation assays or with in vitro colony-forming assays. Such animal studies indicate that tumor stem cell assays can be used to study the properties of tumor stem cells and to delineate differences in individual sensitivities to chemotherapeutic agents (3-6). Furthermore, cloning systems (particularly those developed for culture of macrophage-granulocyte precursors) have proven ideal for the detection and characterization of regulatory factors controlling cell growth and differentiation (7-10).

Although primary explants of plasma cells in transplantable mouse myeloma have been successfully cloned in soft agar $(4,11,12)$, the in vitro cultivation of human plasma cells has met with little success (13-16). Using methods similar to those he described 
for in vitro cultivation of mouse myeloma cells, Park (15) was able to culture human myeloma cells in soft agar. However, he was unable to establish linearity between numbers of cells plated and the number of colonies formed, and thus could not use this technique as an assay system. The lack of an in vitro bioassay for myeloma stem cells has hampered the study of the natural history of myeloma and the quantitation of myeloma stem cell mass.

This paper descirbes a useful in vitro bioassay for human myeloma colony-forming units in culture $(\mathrm{M}-\mathrm{cfu}-\mathrm{c})^{1}$ which we have developed and applied successfully to the study of patients with multiple myeloma and related monoclonal bone marrow-derived (B)-cell neoplasms. Additionally, studies characterizing myeloma colony-forming cells and their growth requirements are reported.

\section{METHODS}

Patient studies. Patients with well-documented multiple myeloma, macroglobulinemia of Waldenström, or benign monoclonal gammopathy, and normal volunteers were selected for study. Detailed clinical and immunologic criteria for diagnosis and clinical staging of myeloma were as described previously (17). Studies which are carried out routinely in our laboratory for case classification in monoclonal neoplasia include immunoelectrophoresis and immunoquantitation of serum and urine M-components, radioimmunoassay measurement of the in vitro synthetic rate of M-component by bone marrow plasma cells $(2,18)$, and measurement of the tritiated thymidine $\left(\left[{ }^{3} \mathrm{H}\right] \mathrm{Tdr}\right)$ labeling index of marrow plasma cells by the high-speed scintillation autoradiography technique (19). Patients are studied during initial staging and before any treatment, as well as at various intervals after treatment. Total body tumor cell number was calculated from M-component measurements, and clinical staging was accomplished by the method of Durie and Salmon (17) and stored along with serial entries using a General Electric time-sharing network (General Electric Information Services, Main Headquarters, Rockville, Md.) which accurately quantitated myeloma cell mass changes with chemotherapy. Remission was defined as a $75 \%$ reduction in total body myeloma cell number. Relapse was defined as a $50 \%$ increase in myeloma cell mass over the remission level. Myeloma patients were treated every 3-4 wk with intermittent 4-day pulse courses of combinations of cyclenonspecific drugs (e.g., melphalan, cyclophosphamide, or doxorubicin hydrochloride) plus prednisone with or without vincristine. Bone marrow samples for in vitro studies on patients receiving chemotherapy were obtained 3-4 wk after the previous course of chemotherapy.

Collection of cells. Bone marrow cells were obtained from patients or normal volunteers by sternal or iliac puncture after informed consent was obtained. Cells were aspirated into a heparinized syringe, mixed in an equal volume of $3 \%$ dextran-saline, and sedimented at room temperature for $45 \mathrm{~min}$. The cells in the supernate were collected after centrifugation at $150 \mathrm{~g}$ for $10 \mathrm{~min}$ and

${ }^{1}$ Abbreviations used in this paper: CSF, colony-stimulating factor; G-cfu-c, granulocyte colony-forming units in culture, $\left[{ }^{3} \mathrm{H}\right] \mathrm{Tdr}$, tritiated thymidine; M-cfu-c, myeloma colony-forming units in culture. washed twice in Hanks' balanced salt solution (HBSS) with $10 \%$ heat-inactivated fetal calf serum. The viable nucleated cell counts determined in a hemocytometer using trypan blue were routinely $>95 \%$. Bone marrow differential counts were performed on slides prepared with cytocentrifuge and stained with Wright-Giemsa stain.

Culture assay for $M-c f u-c$. Colonies derived from myeloma cells were grown in the presence of a 1-ml agar feeder layer in 35-mm Falcon petri dishes (Falcon Plastics, Div. of BioQuest, Oxnard, Calif.). Two types of feeder layers were prepared. The first was made by incorporating $0.02 \mathrm{ml}$ of human type $\mathrm{O}+$ washed erythrocytes in modified McCoy's 5a medium (Grand Island Biological Co., Grand Island, N. Y.) containing 0.5\% agar (Bacto, Difco Laboratories, Detroit, Mich.) to a final volume of $1.0 \mathrm{ml}$. The modified preparation of McCoy's 5a medium consisted of $15 \%$ heat-inactivated fetal calf serum and a variety of nutrients as described by Pike and Robinson (20). Immediately before use, $10 \mathrm{ml}$ of $3 \%$ tryptic soy broth (Grand Island Biological Co.), $0.6 \mathrm{ml}$ asparagine $(0.6 \mathrm{mg} / \mathrm{ml})$, and $0.3 \mathrm{ml}$ DEAE-dextran (Pharmacia Fine Chemicals, Div. of Pharmacia, Inc., Piscataway, N. J.) were added to $40 \mathrm{ml}$ of the enriched medium.

The second feeder layer utilized $0.25 \mathrm{ml}$ of conditioned medium in $0.5 \%$ agar and enriched McCoy's 5a medium. The conditioned medium was prepared from the adherent spleen cells of BALB/c mice which had been primed with $0.2 \mathrm{ml}$ of mineral oil injected intraperitoneally 4 wk previously. This was based on a protocol of Namba and Hanoka for in vitro cultivation of mouse myeloma cells (21). The adherent spleen cells were obtained as follows: the spleens were teased with needles to form a single cell suspension, and $5 \times 10^{6}$ cells were placed in $60-\mathrm{mm}$ Falcon tissue culture dishes in RPMI 1640 medium (Grand Island Biological Co.) containing $20 \%$ horse serum. A 2-h incubation was used to permit cellular adherence. Subsequently, the dishes were rinsed three times in cold phosphatebuffered saline. Cells were then incubated for 3 days at $37^{\circ} \mathrm{C}$ in $5 \mathrm{ml}$ of RPMI 1640 with $15 \%$ heat-inactivated fetal calf serum, penicillin $(100 \mathrm{U} / \mathrm{ml})$, streptomycin $(2 \mathrm{mg} / \mathrm{ml})$, and glutamine $(2 \mathrm{mM})$. The conditioned medium was decanted and centrifuged at $400 \mathrm{~g}$ for $20 \mathrm{~min}$. The supernate was passed through a $0.45-\mu \mathrm{m}$ Nalgene filter (Nalge Co., Nalgene Labware Div., Rochester, N. Y.) and stored up to 1 mo at $-20^{\circ} \mathrm{C}$.

Bone marrow cells to be tested were suspended in $0.3 \%$ agar in CMRL 1066 medium (Grand Island Biological Co.) supplemented with $20 \%$ horse serum, penicillin $(100 \mathrm{U} / \mathrm{ml})$, streptomycin $(2 \mathrm{mg} / \mathrm{ml})$, glutamine $(2 \mathrm{mM}), \mathrm{CaCl}_{2}(4 \mathrm{mM})$, insulin $(3 \mathrm{U} / \mathrm{ml})$, asparagine $(0.6 \mathrm{mg} / \mathrm{ml})$, and DEAEdextran $(0.5 \mathrm{mg} / \mathrm{ml})$ to yield a final concentration of $5 \times 10^{5}$ cells $/ \mathrm{ml}$. Freshly prepared 2-mercaptoethanol was added at a concentration of $50 \mu \mathrm{M}$ immediately before plating the cells (22). $1 \mathrm{ml}$ of the resultant mixture was pipetted onto the $1-\mathrm{ml}$ feeder layer. Cultures were incubated at $37^{\circ} \mathrm{C}$ in $5 \% \mathrm{CO}_{2}$ in a humidified atmosphere with no additional feeding. Cultures were examined in an inverted phase microscope at $\times 100$ and 200 .

Final colony counts were made 14-21 days after plating. Inasmuch as cultures containing erythrocytes were quite opaque, erythrocyte lysis was completed by addition of 0.5 $\mathrm{ml}$ of $3 \%$ acetic acid as necessary before scoring.

Examination of cells in colonies. Individual colonies were removed from the dish using a fine capillary pipette and were suspended in a drop of heat-inactivated fetal calf serum. Colonies were air-dried $3-4 \mathrm{~h}$. Cells were stained routinely with Wright-Giemsa, $0.5 \%$ orcein in $60 \%$ acetic acid, peroxidase (23), and methyl green pyronin (24). 
For detection of cytoplasmic immunoglobulin, slides of individual colonies were air-dried and fixed in cold $\left(-20^{\circ} \mathrm{C}\right)$ spectrophotometric grade acetone for $20 \mathrm{~min}$. Slides were incubated for $45 \mathrm{~min}$ at $20^{\circ} \mathrm{C}$ with $0.025 \mathrm{ml}$ of a $1: 3$ dilution of either fluorescein-conjugated rabbit anti-IgG, IgA, or IgM (Cappel Laboratories, Inc., Cochranville, Pa.). Cells were washed three times in phosphate-buffered saline at $20^{\circ} \mathrm{C}$. Slides were examined in a fluorescent microscope with epi-illumination (American Optical Corp., Scientific Instrument Div., Buffalo, N. Y.). 200 cells per slide were counted. Cells with moderate to strong fluorescence located only in the cytoplasm were scored as positive.

Determination of the percentage of cells in DNA synthesis by $\left[{ }^{3} \mathrm{H}\right] \mathrm{Td}$ killing. The $\left[{ }^{3} \mathrm{H}\right] \mathrm{Tdr}$ "suicide" method of Iscove et al. (25) was employed to measure the proportion of $\mathrm{M}$-cfu-c in the $\mathrm{S}$ phase of the cell cycle. Briefly, samples of $2 \times 10^{6}$ cells, suspended in HBSS and $10 \%$ heatinactivated fetal calf serum, were added to $1 \mathrm{ml}$ of HBSS containing $40 \mu \mathrm{Ci}$ of $\left[{ }^{3} \mathrm{H}\right] \mathrm{Tdr}(23 \mathrm{Ci} / \mathrm{mm}$, AmershamSearle Corp., Arlington Heights, Ill.). Control samples were added to HBSS. Cell suspensions were then incubated for $30 \mathrm{~min}$ at $37^{\circ} \mathrm{C}$, and washed twice with $20 \mathrm{ml}$ of icecold HBSS containing $100 \mu \mathrm{g} / \mathrm{ml}$ of unlabeled thymidine and $10 \%$ fetal calf serum. Each suicide and control suspension was cultured in four replicate plates at a concentration of $5 \times 10^{5}$ nucleated cells per plate.

Cell separation by velocity sedimentation. Cell suspensions were separated by velocity sedimentation at unit gravity using the Staput method of Miller and Phillips (26). This technique separates cells primarily on the basis of size. Briefly, $1 \times 10^{8}$ cells, suspended in phosphate-buffered saline with $5 \%$ fetal calf serum were sedimented through a $15-30 \%$ fetal calf serum gradient in a cylindrical siliconized glass chamber $18 \mathrm{~cm}$ in diameter (Johns Scientific Co., Toronto, Ontario, Canada). Sedimentation was carried out at $4^{\circ} \mathrm{C}$ for $150 \mathrm{~min}$, and the chamber was then drained. The first $250 \mathrm{ml}$, consisting of the fluid in the conical portion of the chamber, was discarded. The remainder of the gradient was collected in $50-\mathrm{ml}$ fractions. Cells were centrifuged at $150 \mathrm{~g}$ for $10 \mathrm{~min}$ and washed. Nucleated cell counts for each fraction were made in a hemocytometer after dilution in $3 \%$ acetic acid, and cytocentrifuge preparations were made.
Preparation of nonadherent and nonphagocytic cell populations. Freshly washed bone marrow cells were further separated into adherent and nonadherent populations by the method of Messner et al. (27). Briefly, cells were allowed to adhere for $30 \mathrm{~min}$ to $60-\mathrm{mm}$ plastic tissue culture dishes in RPMI 1640 medium and $15 \%$ fetal calf serum at $37^{\circ} \mathrm{C}$. The supernate was decanted, and the adherence procedure was repeated three more times to provide the nonadherent cell population.

Bone marrow cells were depleted of phagocytic cells by placing $10^{7}$ washed cells in tubes with $40 \mathrm{mg}$ of carbonyl iron powder (Tridom-Fluka, Hauppage, N. Y.) and incubating the mixture in a shaking water bath at $37^{\circ} \mathrm{C}$. After $30 \mathrm{~min}$, the iron powder and iron-laden cells were attracted to the bottom of the flask with a magnet. The supernate was carefully poured off, and this step was repeated as often as necessary (generally two to three times) to remove all the iron powder and iron-laden phagocytic cells. The remaining cells in the supernate were considered nonphagocytic.

Assay for granulopoietic colony formation. The assay used for granulocyte colony formation by human bone marrow cells was described by Pike and Robinson (20).

\section{RESULTS}

Development and identification of colonies. Cell doublings were usually observed within $48 \mathrm{~h}$ of plating and clusters of 8-40 cells appeared within 5-10 days. Colonies (collections of more than 40 cells) appeared 14-21 days after plating. Cell lysis generally occurred 28 days after plating. During the 1st wk of incubation there was a progressive increase in the number of cells which commenced proliferation. Colonies consisted of 40 to several hundred large $(>20 \mu \mathrm{m})$ round cells. Cells in myeloma colonies appeared to pile up on one another (Fig. 1A) as opposed to loosely aggregated cells in contaminating granulocyte colonies. Growth kinetics of human myeloma cells in agar were similar to those described by Park (15).
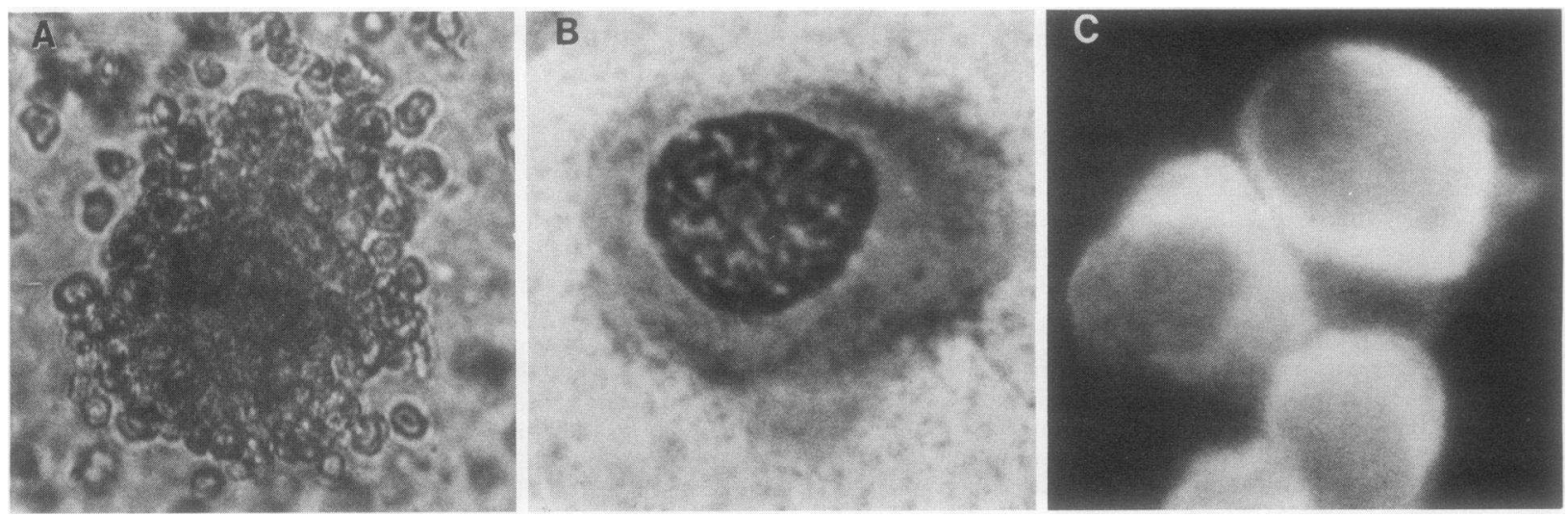

FIGURE 1 (A) A typical myeloma colony from a 21-day-old culture grown from the bone marrow of a patient in relapse $(\times 20)$. (B) A plasma cell picked from a 21-day-old culture and stained with Wright-Giemsa $(\times 100)$. (C) Cells from a colony grown from the bone marrow of a patient with IgG myeloma. Cells were fixed in acetone and stained directly with fluorescent anti-human IgG. Note the strong specific cytoplasmic fluorescence $(\times 100)$. 


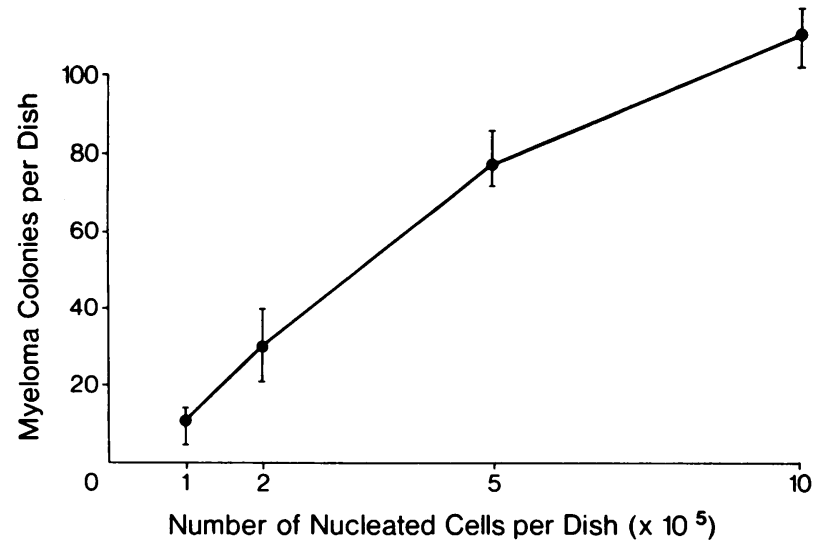

FIGURE 2 Linear relationship between colony formation and the number of nucleated bone marrow cells plated. Each point represents the mean of four dishes $\pm S E M$. These are the results of a typical experiment. Three other trials on different patients have yielded similar results.

The number of myeloma colonies ranged from 5 to 500 per plate, yielding a cloning efficiency of $0.001-$ $0.1 \%$. A linear relationship was obtained between the number of nucleated cells plated and the number of colonies found after 21 days (Fig. 2). The plot could be back-extrapolated through zero, suggesting colony origin from a single cell.

Cells from individual colonies when plucked from agar appeared to be plasma cells when examined by light microscopy after staining with Wright-Giemsa or methyl green pyronin (Fig. 1B). In Wright-Giemsastained preparations, the day 5-8 colonies were composed of a population of large mononuclear cells with bulky basophilic cytoplasm. However, colonies from older cultures contained mature plasma cells.

Cells were peroxidase-negative and incapable of phagocytosis of neutral red or latex particles. Immunofluorescent studies demonstrated that $60-80 \%$ of the myeloma cells of individual colonies had the cytoplasmic immunofluorescence specific for the monoclonal immunoglobulin present in the serum of the patient studied (Fig. 1C).

To study the cell renewal capability of the M-cfu-c, serial replating studies were carried out on myeloma colony plates from one patient (R. B.). In serial experiments, clusters and colonies of 2-, 5-, and 8-day incubations were plucked from the agar with a micropipette. The harvest of a given day was pooled, resuspended in medium, and passed through a 23gauge needle for dispersion. The resulting singlecell suspension was then replated at $5 \times 10^{5}$ cells per plate over a fresh feeder layer. Despite the potential disruption and stem cell death which can result from such transfer experiments, clusters and colonies harvested as described above were capable of forming secondary myeloma colonies in the range of 100 colonies per plate, indicating some preservation of the primary colony-forming units in the culture system. In companion studies, washed cells plucked from myeloma colonies were incubated for varying times up to $24 \mathrm{~h}$ at $37^{\circ} \mathrm{C}$ in suspension culture along with tritiated leucine. The supernatant culture fluid from these cultures was then subjected to the solid-phase radioimmunoassay for intrinsically labeled IgG standardized in our laboratory (18). Cells from myeloma colonies were found to be capable of secreting IgG in quantities quite similar to myeloma cells from bone marrow samples $(1,2)$. The myeloma colonies were therefore operationally defined as arising from myeloma stem cells.

Factors affecting cell growth. Substitution of type $A, B$, or AB erythrocytes usually resulted in decreased numbers of colonies, although differences were not statistically significant. Mouse erythrocytes appeared to be cytotoxic. Lysates of $O$ cells also supported growth. Depletion of residual colonystimulating factor-producing leukocytes from erythrocytes by Ficoll-Hypaque (Pharmacia Fine Chemicals) or carbonyl iron methods did not affect colony growth (Table I).

Media conditioned with spleen cells of CD-1, DBA/2, and normal BALB/c mice were not so effective promoters of cell growth as conditioned media from oil-primed BALB/c mice. Conditioned media from WI 38 cells, MA 184 cells (bone marrow fibroblasts), or primary explants of human skin fibroblasts were unable to support cell growth. Bacterial lipopolysaccharide, mouse peritoneal exudate cells, mouse kidney fibroblasts, or frozen and thawed human leukemic bone marrow cells failed to stimulate myeloma cell growth. Serum from mice injected with endotoxin, bacterial antigens, or mineral oil did not allow colony growth. Autologous serum or urine from myeloma patients had no effect on colony growth.

The addition of ascorbic acid to culture of murine plasmacytoma cells has been reported by Park et al. to stimulate colony growth (4). Although vitamin Crich CMRL enhanced cell growth, experiments using aged CMRL (depleted of vitamin C) failed to demonstrate the absolute requirement for vitamin $\mathrm{C}$ for myeloma colony growth (Table II).

Effect of clinical status on cell growth. Myeloma colony growth has been achieved in marrows from $83 \%$ of untreated patients or those in relapse (Table III). Only $50 \%$ of bone marrows from patients in remission on chemotherapy have formed myeloma colonies. Plasma cell colony growth was observed from the bone marrows of patients with benign monoclonal gammopathy or macroglobulinemia of Waldenström (Table III). The kinetics of plasma cell colony formation in these monoclonal disorders were 
TABLE I

Effect of Substitution of Alternative Feeder Layers on Myeloma Colony Formation

\begin{tabular}{|c|c|c|}
\hline & \multicolumn{2}{|c|}{$\begin{array}{l}\text { Number of colonies } \\
\left(\text { per } 5 \times 10^{5} \text { cells }\right) \ddagger\end{array}$} \\
\hline & Control (O cell) & Experimental \\
\hline \multicolumn{3}{|l|}{ Erythrocyte feeder layers } \\
\hline Substituted material $(0.02 \mathrm{ml})$ & & \\
\hline O RBC* lysate & $158 \pm 13.0$ & $134 \pm 8.5$ \\
\hline $\begin{array}{l}\text { O RBC depleted of WBC } \\
\text { with Hypaque-Ficoll } \\
\text { gradient }\end{array}$ & $40+80$ & $49+58$ \\
\hline $\begin{array}{l}\text { O RBC depleted of WBC } \\
\text { with Hypaque-Ficoll } \\
\text { gradient followed by }\end{array}$ & & \\
\hline $\begin{array}{l}\text { carbonyl-iron } \\
\text { A RBC }\end{array}$ & $\begin{array}{l}40 \pm 8.0 \\
98+110\end{array}$ & $\begin{array}{l}41 \pm 4.6 \\
74+5\end{array}$ \\
\hline $\begin{array}{l}\text { A RBC } \\
\text { B RBC }\end{array}$ & $\begin{array}{l}98 \pm 11.0 \\
98 \pm 11.0\end{array}$ & $\begin{array}{l}74 \pm 5.2 \\
80 \pm 2.5\end{array}$ \\
\hline AB RBC & $98 \pm 11.0$ & $88 \pm 6.1$ \\
\hline \multirow[t]{2}{*}{ BALB/c (mouse) RBC } & $98 \pm 11.0$ & 0 \\
\hline & $\begin{array}{l}\text { Control (oil- } \\
\text { primed BALB/c)\$ }\end{array}$ & Experimental \\
\hline \multirow{2}{*}{\multicolumn{3}{|c|}{$\begin{array}{l}\text { Conditioned-medium feeder } \\
\text { layers } \\
\text { Cell source }\end{array}$}} \\
\hline & & \\
\hline Normal BALB/c mice $\S$ & $45 \pm 9.6$ & $12 \pm 2.3$ \\
\hline CD-1 mice (oil-primed) $\S$ & $48 \pm 9.6$ & $22 \pm 6.5$ \\
\hline DBA/2 mice (oil-primed) $\S$ & $45 \pm 9.6$ & $8 \pm 2.3$ \\
\hline WI38 (human fibroblasts) & $45 \pm 9.6$ & $2.0 \pm 2$ \\
\hline $\begin{array}{l}\text { MA } 194 \text { (human marrow } \\
\text { fibroblasts) }\end{array}$ & $45 \pm 9.6$ & $1.8 \pm 1$ \\
\hline $\begin{array}{l}\text { Primary skin fibroblasts } \\
\text { (human) }\end{array}$ & $48 \pm 9.6$ & 0 \\
\hline
\end{tabular}

* RBC, erythrocytes; WBC, leukocytes.

$\$$ Mean \pm SEM.

$\$$ Adherent spleen cells (Methods).

similar to those observed in myeloma. Normal bone marrow cells failed to grow plasma cell colonies when plated under these culture conditions. One of the normal donors had a $15 \%$ plasmacytosis 4 wk after an upper respiratory infection, but failed to form plasma cell colonies. The small number of colonies

TABLE II

Effect of L-Ascorbic Acid on Colony Formation of Human Myeloma Cells

\begin{tabular}{cc}
\hline $\begin{array}{c}\text { Storage of medium } \\
\text { used for plating }\end{array}$ & $\begin{array}{c}\text { Myeloma colonies per } \\
5 \times 10^{\circ} \text { cells }\end{array}$ \\
\hline $1 \mathrm{mo}$ at $-20^{\circ} \mathrm{C}$ & $91 \pm 4$ \\
$1 \mathrm{mo}$ at $4^{\circ} \mathrm{C}$ & $58 \pm 5$ \\
1 mo at $4^{\circ} \mathrm{C}$ with $0.3 \mathrm{mM}$ & \\
L-ascorbic acid & $67 \pm 6$ \\
\hline
\end{tabular}

TABLE III

Relation of Patient Status to Monoclonal Plasma Cell Colony Growth

\begin{tabular}{lccc}
\hline Patient status & $\begin{array}{c}\text { Number of positive } \\
\text { cultures/total } \\
\text { studied subjects }\end{array}$ & $\begin{array}{c}\text { Suc- } \\
\text { cessful }\end{array}$ & $\begin{array}{c}\text { Number }( \pm \text { SEM) of } \\
\text { colonies/10 cells } \\
\text { plated }\end{array}$ \\
\hline Multiple myeloma & & $\%$ & \\
$\quad$ Untreated & $13 / 16^{*}$ & 81 & $105 \pm 15.0$ \\
Remission & $12 / 24^{*}$ & 50 & $42 \pm 34.7$ \\
Relapse & $21 / 25^{*}$ & 84 & $67 \pm 11$ \\
Macroglobulinemia of & & & \\
Waldenström & $2 / 2$ & 100 & $50 \pm 8$ \\
$\quad$ Untreated & $2 / 3$ & 66 & $11 \pm 7.6$ \\
Benign monoclonal & $0 / 1$ & 0 & 0 \\
gammopathy & $2 / 10 \pm$ & $20 \pm$ & $4 \pm 4^{*}$ \\
Reactive plasmacytosis & & & \\
Normal & & & \\
\hline
\end{tabular}

* Comparison of no. of positive cultures/total subjects studied shows significantly higher rate of culture positivity in the combined group of untreated and relapse patients $(34 / 41)$ vs. patients in remission $(12 / 24)$ with the $P$ value as determined by Fisher exact probability test $<0.005$.

I Granulocyte colony formation occurred in 2 of the 10 normal marrows tested, and are recorded as "positive." In all other subjects studied, colonies consisted of plasma cells.

that occasionally grew from normal marrow were peroxidase-positive and were granulocytes.

Proliferative state of $M-c f u-c$. High specific activity $\left[{ }^{3} \mathrm{H}\right] \mathrm{Tdr}$ was used to determine the percentage of M-cfu-c in the DNA synthetic (S phase) of the cell cycle (Table IV). $\left[{ }^{3} \mathrm{H}\right] \mathrm{Tdr}(40 \mu \mathrm{Ci} / \mathrm{ml})$ reduced colony survival to as little as $18 \%$ of control. Increasing the $\left[{ }^{3} \mathrm{H}\right] \mathrm{Tdr}$ concentration to $400 \mu \mathrm{Ci} / \mathrm{ml}$ did not further increase the suicide fraction in either of two experiments. The addition of cold thymidine to $\left[{ }^{3} \mathrm{H}\right] \mathrm{Tdr}$ completely blocked the suicide effect in three experiments. The relationship of clinical status and various tumor kinetics parameters, including the suicide index, are summarized in Table IV. No suicide effect occurred in two patients (J. H. and V. W.) who had heavy infiltration of the marrow with myeloma cells and low $\left[{ }^{3} \mathrm{H}\right] \mathrm{Tdr}$ labeling indices.

Sedimentation velocity analysis of M-cfu-c. The sedimentation velocity of M-cfu-c was determined using the Staput apparatus. A representative experiment using bone marrow cells from an untreated myeloma patient is depicted in Fig. 3. Three additional experiments with cells from other myeloma patients have yielded similar results. In contrast to the nucleated cell profile obtained from normal bone marrow (28), myeloma bone marrow contained a large population of rapidly sedimenting cells. Myeloma stem cells sedimented as a single broad band with a peak sedimentation velocity of $13 \mathrm{~mm} / \mathrm{h}$. This value is in good agreement with that of Park who reported that M-cfu-c sedimented at $12 \mathrm{~mm} / \mathrm{h}$ (15).

In an additional experiment, marrow cells from a second myeloma patient were separated on a Staput 
TABLE IV

Relation of Clinical and Tumor Kinetic Parameters in Patients with Multiple Myeloma

\begin{tabular}{|c|c|c|c|c|c|c|c|c|c|}
\hline Patient & M-Component & $\begin{array}{c}\text { Clinical } \\
\text { stage at } \\
\text { diagnosis* }\end{array}$ & $\begin{array}{l}\text { Status } \\
\text { when } \\
\text { studied }\end{array}$ & $\begin{array}{c}\text { Bone } \\
\text { marrow } \\
\text { myeloma } \\
\text { cells }\end{array}$ & $\begin{array}{c}\text { Myeloma cell } \\
{\left[{ }^{3} \mathrm{H}\right] \mathrm{Tdr} \text { labeling }} \\
\text { index }\end{array}$ & $\begin{array}{c}\text { Total body } \\
\text { myeloma cell } \\
\text { number when } \\
\text { studied }\end{array}$ & $\begin{array}{c}\text { M-cfu-c } \\
10^{8} \text { myeloma } \\
\text { cells } \S\end{array}$ & $\begin{array}{l}\text { Plating } \\
\text { efficiency }\end{array}$ & $\begin{array}{c}\text { Fraction of } \\
\text { M-cfu-c } \\
\text { surviving } \\
{\left[{ }^{3} \mathrm{H}\right] \mathrm{Tdr}} \\
\text { suicide }\end{array}$ \\
\hline & & & & $\%$ & $\%$ & & & $\%$ & \\
\hline R. B. & $\operatorname{IgG} \lambda$ & IIA & Untreated & 36 & 2 & $2.24 \times 10^{12}$ & $1,772 \pm 1.78$ & 0.18 & 0.18 \\
\hline J. H. & $\kappa-\mathrm{BJ}$ & IIIB & Untreated & 90 & 1 & $7.02 \times 10^{12}$ & $240 \pm 20$ & 0.02 & 1.25 \\
\hline U. T. & $\lambda \mathrm{BJ}$ (amyloid) & IB & Remission & 4 & 1 & $0.98 \times 10^{12}$ & $190 \pm 23$ & 0.02 & 0.25 \\
\hline E. F. & $\operatorname{IgG} \lambda$ & IIIA & Relapse & 25 & 2 & $0.36 \times 10^{12}$ & $560 \pm 110$ & 0.06 & 0.36 \\
\hline V. W. & $\operatorname{IgAK}$ & IIIA & Relapse & 73 & 1 & $3.69 \times 10^{12}$ & $300 \pm 50$ & 0.03 & 1.21 \\
\hline
\end{tabular}

* Clinical staging as described in reference 17 .

‡ Calculated from initial cell mass from regression equation from reference 15, and corrected for change in M-component mass with remission or relapse.

$\S$ All cultures were plated at $5 \times 10^{5}$ total nucleated marrow cells per plate, and are normalized to $10^{6}$ with correction for plasma cell percentage. Plating efficiency for $\mathrm{M}-\mathrm{cfu}-\mathrm{c}$ was calculated in relation to the number of myeloma cells plated.

gradient, after which fractions were split, and cells were plated in either a granulocyte culture assay or the myeloma culture system. The number of granulocyte (G-) or M-cfu-c were evaluated in each fraction. The results are shown in Fig. 4. G-cfu-c sedimented much more slowly than M-cfu-c. There were approximately 10 times as many G-cfu-c in this marrow as M-cfu-c.

Effect of depletion of phagocytic or adherent cells. Although no exogenous source of colony-stimulating factor (CSF) is supplied in our culture system, adherent phagocytic cells of the bone marrow produce endogenous CSF that permits granulocyte growth (29). Therefore, bone marrow suspensions were depleted

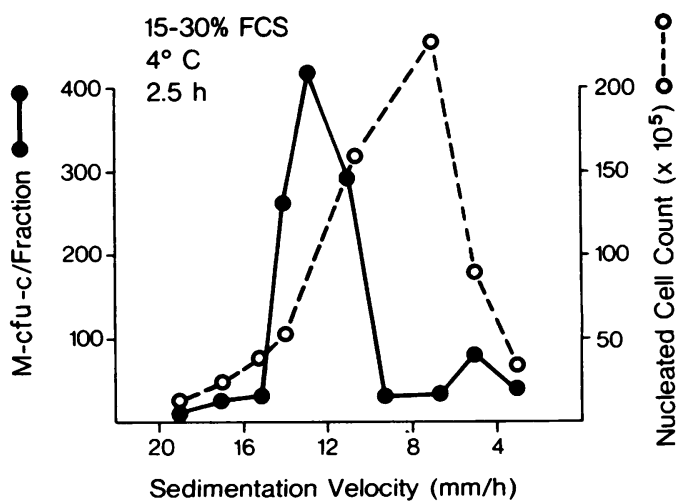

FIGURE 3 Results of a typical sedimentation velocity separation of cells from a bone marrow of a myeloma patient in relapse. $10^{8}$ cells were sedimented through a $15-30 \%$ fetal calf serum (FCS) gradient at $4^{\circ} \mathrm{C}$ for $150 \mathrm{~min}$. The dotted line represents the nucleated cell profile; the unbroken line the M-cfu-c profile. of either adherent or phagocytic cells, or both populations, before plating. In every case (Table V), depletion of the phagocytic or adherent cells increased the number of myeloma colonies seen per $5 \times 10^{5}$ cells. Thus, CSF-producing cells were not required for colony formation.

Effect of anti-CSF serum on myeloma colony formation. A rabbit antiserum to CSF prepared against mouse L cell CSF by Shadduck and Metcalf (30) was added to cultures to determine if myeloma

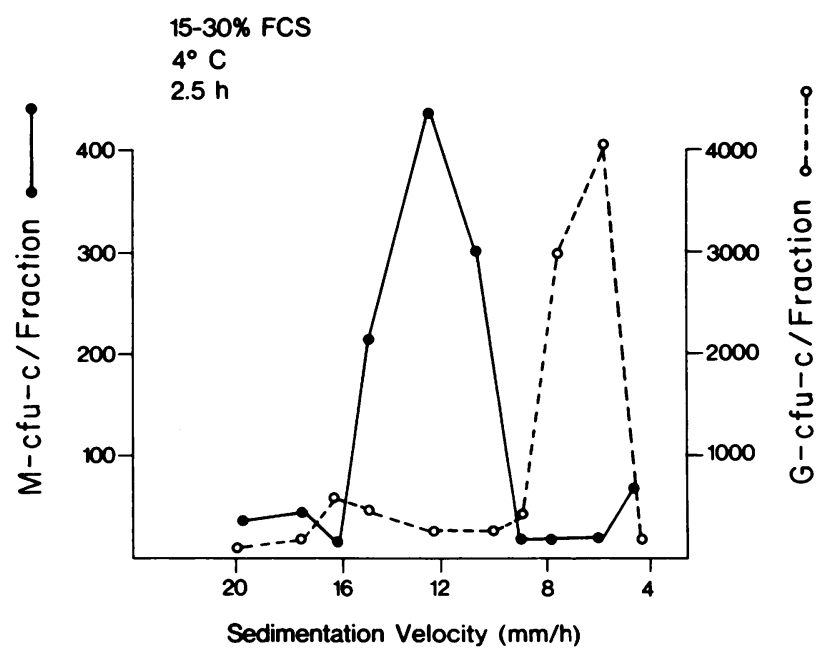

FIgURE 4 Results of a sedimentation velocity separation of cells from a bone marrow of a second myeloma patient in relapse. Cells were sedimented as described, fractions were split, and cells were grown in either a granulocyte or myeloma culture assay. The unbroken line represents the number of $M-c f u-c$ per fraction; the dotted line represents the number of G-cfu-c per fraction. FCS, fetal calf serum. 
TABLE V

Effect of Population Depletion on Myeloma Colony Formation

\begin{tabular}{cccc}
\hline & & \multicolumn{2}{c}{$\begin{array}{c}\text { Number of M-cfu-c/5 } \times 10^{5} \\
\text { cells plated* }\end{array}$} \\
\cline { 2 - 4 } $\begin{array}{c}\text { Population } \\
\text { depleted }\end{array}$ & Exp & Before depletion & After depletion \\
\hline Adherent & 1 & $11 \pm 7.2$ & $92 \pm 8.3$ \\
& 2 & $52 \pm 8.7$ & $83 \pm 6.8$ \\
& 3 & $65 \pm 8.6$ & $101 \pm 11.2$ \\
& 4 & $28 \pm 5.6$ & $123 \pm 9.8$ \\
Adherent & 5 & $44 \pm 4.8$ & $220 \pm 28.5$ \\
phagocytic & 5 & $48 \pm 8.1$ & $80 \pm 22.0$ \\
Phagocytic & 6 & $70 \pm 14.5$ & $200 \pm 37.4$ \\
\hline
\end{tabular}

Mean \pm SEM of four plates.

colony formation was dependent on CSF and to eliminate the possibility that significant numbers of granulocyte colonies were growing in these cultures. The top portion of Table VI shows the results of a control experiment to determine the potency of the rabbit antiserum to CSF on granulocyte colony formation (30). Normal human bone marrow was plated in a standard Pike-Robinson granulocyte assay (20). The results indicated a $50 \%$ inhibition of colony formation at a serum dilution of 1:8. Normal rabbit serum did not depress granulocyte colony growth. The results of adding anti-CSF to bone marrow cells from myeloma patients in relapse cultured in our system are presented on the bottom of Table VI. Anti-CSF did not inhibit myeloma colony growth.

TABLE VI

Effect of Anti-CSF on Colony Formation by G- and M-cfu-c

\begin{tabular}{ccc}
\hline \multirow{2}{*}{$\begin{array}{c}\text { Reciprocal of } \\
\text { serum dilution }\end{array}$} & \multicolumn{2}{c}{ Number of colonies $/ 5 \times 10^{5}$ cells } \\
\cline { 2 - 3 } & Anti-CSF & NRS $^{*}$ \\
\hline G-cfu-c & & \\
No serum & $209 \pm 21.4$ & $209 \pm 21.4$ \\
16 & $182 \pm 19.2$ & $198 \pm 16.4$ \\
8 & $64 \pm 9.3$ & $230 \pm 18.1$ \\
4 & $38 \pm 3.5$ & $173 \pm 32.1$ \\
2 & $55 \pm 9.8$ & $192 \pm 30.7$ \\
M-cfu-c & & \\
No serum & $366 \pm 25.7$ & $366 \pm 25.7$ \\
16 & $331 \pm 29.8$ & $322 \pm 28.8$ \\
8 & $345 \pm 13.1$ & $320 \pm 28.1$ \\
4 & $380 \pm 30.5$ & $365 \pm 60.0$ \\
2 & $316 \pm 40.8$ & $292 \pm 15.9$ \\
\hline
\end{tabular}

Each point based on four plates \pm SEM. $0.1 \mathrm{ml}$ of diluted antiserum was added to each plate.

* NRS indicates normal rabbit serum.

\section{DISCUSSION}

The present studies have shown that bone marrow cells from patients with multiple myeloma and related monoclonal disorders were capable of forming colonies of monoclonal plasma cells in soft agar. Growth was most easily achieved from bone marrows of untreated patients or those in relapse. A variety of morphological, histochemical, and immunofluorescent stains demonstrated that colonies consisted of plasma cells at different maturational stages. The immunochemical and cytochemical stains as well as the experiments with anti-CSF and depletion of bone marrow of CSF-producing cells indicated that the colonies did not consist of macrophages or granulocytes, nor did they require the stimuli for growth requisite for those myeloid cell types.

The fact that the number of colonies seen was directly proportional to the number of cells plated suggests that colonies were clones derived from single cells. This conclusion was supported by repeated observations of the development of colonies starting from a single cell. Plating efficiency, although low, was in the same range as that observed for granulocyte and erythroid colony-forming cells. Therefore, despite this low plating efficiency, our assay should prove useful in determining properties of myeloma stem cells and factors governing their proliferation in the same manner that in vitro assays have proven useful in elucidating G-cfu-c behavior. However, these low plating efficiencies could possibly lead to large sampling errors and ultimately affect estimates of the stem cell pool.

The nature of the potentiating effect of either erythrocytes or conditioned medium requires much further analysis. Metcalf $(11,12)$ has reported that intact mouse erythrocytes potentiated growth of murine plasmacytomas in vitro. However, this activity was lost when erythrocytes were lysed. In contrast, lysates of human erythrocytes supported myeloma cell growth. This might suggest that a different mechanism is involved in the potentiation of human plasma cell growth. Whether the factor(s) provided by erythrocytes and conditioned medium were similar remains to be determined.

In addition, the role of 2-mercaptoethanol remains unclear, although its helper effect in a variety of immunological reactions (31) and a clonal assay for mouse B lymphocytes has been well documented (22). It is possible that mercaptoethanol substitutes for a specific metabolite or induces the formation of a growth regulator in a fashion analogous to its promotion of release of CSF from lymphoid cells (32).

The absolute necessity of any of the additions to the CMRL overlay or the McCoy's medium feeder layer has not been documented. The use of horse 
serum was prompted by reports of Park et al. (4) that high levels of fetal calf serum inhibited in vitro growth of murine plasmacytomas. We have noted a similar effect of fetal calf serum on human M-cfu-c growth. The use of human serum was avoided to minimize growth of granulocyte colonies (33).

We believe our in vitro technique will be useful in studying the growth kinetics of human myeloma. Prior studies from our laboratory have shown that the total body tumor mass in myeloma is in the range of $10^{12}$ cells at the time of diagnosis, with death occurring after two to three more doublings in total body tumor burden. Assuming that our in vitro colony assay does measure myeloma stem cells, then (based on our highest plating efficiencies of $0.2 \%$ ) the minimum number of myeloma cells in the tumor stem cell compartment is in the range of $10^{9}$ at the time of diagnosis. Our $\left[{ }^{3} \mathrm{H}\right] \mathrm{Td}$ suicide studies suggest that in most patients a very high proportion of M-cfu-c are in the cell cycle. If we assume that the total cell cycle duration is equal to twice the S-phase duration, then it would appear that the median fraction of myeloma stem cells in cycle in the patients studied was $72 \%$. Of interest, there was no reduction in the number of M-cfu-c with $\left[{ }^{3} \mathrm{H}\right] \mathrm{Tdr}$ suicide in the two patients studied who had the highest concentrations of myeloma cells in the bone marrow (73 and $90 \%$ ). The high concentration of total myeloma cells in these marrows may have transiently halted cycling or promoted entry into the $\mathrm{G}_{0}$ compartment. The relatively high median $\left[{ }^{3} \mathrm{H}\right] \mathrm{Tdr}$ suicide index for M-cfu-c is in sharp contrast to the low proportion of marrow myeloma cells which appear to be in the $\mathrm{S}$ phase as measured by autoradiography with the $\left[{ }^{3} \mathrm{H}\right] \mathrm{Tdr}$ labeling index. The labeling index in untreated patients is generally <3\% (34-36). By comparing the labeling index results to those of $\left[{ }^{3} \mathrm{H}\right] \mathrm{Tdr}$ suicide studies of M-cfu-c (Table IV) it appears likely that the M-cfu-c make up a sizeable proportion of those cells which can be identified as being in cycle with the labeling index.

The high suicide index and the relatively prompt appearance of 40-cell myeloma colonies in vitro suggest that human myeloma stem cells can proliferate rapidly. For example, if a myeloma colony contains 64 cells in 18 days, the in vitro doubling time is 3 days. Our previous marker kinetic studies based on M-component synthesis and metabolism indicated that myeloma grew in accord with Gompertzian kinetics. Despite the fact that the in vivo doubling time for a myeloma clone in the clinical phase of disease $\left(5 \times 10^{11}-5 \times 10^{12}\right.$ cells $)$ was in the range of 2-6 mo, we could back-calculate from the growth or regression curves and predict a median initial tumor doubling time (one cell to two) of 1.88 days (2). Our in vitro colony-forming studies now provide inde- pendent evidence that when human myeloma stem cells are present in low cell concentrations, growth can proceed rapidly. It was of interest to observe that monoclonal colonies from macroglobulinemia and benign monoclonal gammopathy grew with equal vigor. Although we studied few cases, we speculate that differences in the in vivo environment or feedback regulation could account for the more indolent clinical behavior of those two neoplasms. Additional studies will be necessary to further assess plasma cell colony growth patterns in these latter disorders.

In addition to clarifying the cellular kinetics of myeloma, it appears that such assays will prove to have clinical importance. Specifically, in vitro tumor colony-forming assays have been used for detailed studies of drug and radiation sensitivity of mouse myeloma stem cells and have been predictive of in vivo results (6). In preliminary experiments, we have observed individual differences in sensitivity of human M-cfu-c from different patients to melphalan, 1,3bis(2-chloroethyl)-1-nitrosourea, and doxorubicin hydrochloride. Previous studies from our laboratory relating total tumor mass staging to response to treatment and survival (17) suggested that tumor mass per se, while predictive of survival, was only of modest value in prediction of response to treatment. At that time we conjectured that the major measured predictive factor was drug sensitivity itself. Individualized studies of drug sensitivity of myeloma colonies may therefore have potential use for predictive cancer chemotherapy of multiple myeloma. We have now initiated a study to determine, both retrospectively and prospectively, if the in vitro survival of a patient's cells to drugs correlates with the clinical response to chemotherapy. A large number of such observations will be necessary to determine if the technique will be of value in predicting patients' response to treatment.

\section{ACKNOWLEDGMENTS}

We wish to thank Mary Kim, Yvette Frutiger, and Barbara Soehnlen for skilled technical assistance, and Dr. Brian G. M. Durie for clinical assistance. We also wish to thank the Ontario Cancer Institute and its investigators for sending us a copy of Dr. Chan Park's Ph.D. dissertation in which he reviewed his innovative murine work and his preliminary human studies.

This work was supported in part by grants CA-14102 and CA-17094 from the U. S. Public Health Service as well as a contract, CM-73-33713, from the National Cancer Institute.

\section{REFERENCES}

1. Salmon, S. E. 1973. Immunoglobulin synthesis and tumor kinetics of multiple myeloma. Semin. Hematol. 10: $135-147$.

2. Sullivan, P., and S. E. Salmon. 1972. Kinetics of tumor 
growth and regression in IgG multiple myeloma. J. Clin. Invest. 51: 1697-1706.

3. Ogawa, M., D. Bergsagel, and E. McCulloch. 1973. Chemotherapy of mouse myeloma: quantitative cell culture predictive of response in vivo. Blood. 41: 7-15.

4. Park, C. H., D. Bergsagel, and E. McCulloch. 1971. Mouse myeloma tumor stem cells: a primary cell culture assay. J. Natl. Cancer Inst. 46: 411-416.

5. Ogawa, M., D. Bergsagel, and E. McCulloch. 1971. Differential effect of melphalan on mouse myeloma (Adj. PC-5) and hemopoietic stem cells. Cancer Res. 31: 2116-2119.

6. Ogawa, M., D. Bergsagel, and E. McCulloch. 1973. Sensitivity of human-murine hemopoietic precursor cells to chemotherapeutic agents assessed in cell culture. Blood. 42: 851-858.

7. Bradley, T., and D. Metcalf. 1966. The growth of mouse bone marrow in vitro. Aust. J. Exp. Biol. Med. Sci. 4: 287-299.

8. Pluznik, D., and L. Sachs. 1966. The induction of clones of normal mast cells by a substance from conditioned media. Exp. Cell Res. 43: 553-563.

9. Stephenson, J., A. Axelrod, D. McLeod, and M. Shreeve. 1972. Induction of colonies of hemoglobin synthesizing cells by erythropoietin in vitro. Proc. Natl. Acad. Sci. U. S. A. 68: 1542-1546.

10. Tepperman, A., J. Curtin, and E. McCulloch. 1974. Erythropoietic colonies in culture of human marrow. Blood. 44: 659-669.

11. Metcalf, D. 1973. Colony formation in agar by mouse plasmacytoma cells: potentiation by hemopoietic cells and serum. J. Cell Physiol. 81: 397-410.

12. Metcalf, D. 1974. The serum factor stimulating colony formation in vitro by murine plasmacytoma cells: response to antigens and mineral oil. J. Immunol. 113: 235-243.

13. Johns, M., J. Fahey, and Z. Price. 1974. Long term establishment of a human plasmacyte cell line derived from a patient with IgD multiple myeloma. J. Exp. Med. 140: 494-507.

14. Nilson, K., H. Bennich, G. Johanson, and J. Porter. 1970. Establishment of immunoglobulin producing myeloma (IgE) and lymphoblastoid (IgG) cell lines from an IgE myeloma patient. Clin. Exp. Immunol. 7: 477-480.

15. Park, C. 1971. Studies of the growth characteristics of myeloma in vitro. Ph.D. dissertation, University of Toronto. 31-61.

16. Beckmann, H., R. Neth, H. Sohau, J. Ritter, K. Winkler, M. Garbrecht, K. Hausmann, and G. Rutter. Plasma cells and blast proliferation of leukemic human hemopoietic cells in vitro. In Progress in Differentiation Research. N. Muller-Berat, editor. American Elsevier Publishing Co., Inc., Elsevier North-Holland, Inc., New York, 383-395.

17. Durie, B., and S. Salmon. 1975. A clinical staging system for multiple myeloma. Cancer. 36: 842-854.

18. Salmon, S., and B. Smith. 1970. Immunoglobulin synthe- sis and total body tumor cell number in IgG multiple myeloma. J. Clin. Invest. 49: 1114-1119.

19. Durie, B., and S. Salmon, 1975. High speed scintillation autoradiography. Science (Wash. D. C.). 190: 1093-1095.

20. Pike, B., and W. Robinson. 1970. Human bone marrow colony growth in vitro. J. Cell Physiol. 76: 77-81.

21. Namba, Y., and M. Hanoka. 1972. Immunocytology of cultured IgM forming cells of mice. J. Immunol. 109: 1193-1200.

22. Metcalf, D., G. Nossal, N. Warner, J. Miller, T. Mandell, J. Layton, and G. Gutman. 1975. Growth of B-lymphocyte colonies in vitro. J. Exp. Med. 142: 1539-1545.

23. Todd, J. C., and A. H. Sandford. 1962. The Blood. In Clinical Diagnosis by Laboratory Methods. I. Davidson and D. Wells, editors. W. B. Saunders Company, Philadelphia. 131-132.

24. Weinberg, S., and F. Stohlman. 1976. Growth of mouse yolk sac cells cultured in vivo. Br. J. Haematol. 32: 543-558.

25. Iscove, N., J. Till, and E. McCulloch. 1970. The proliferative state of mouse granulopoietic progenitor cells. Proc. Soc. Exp. Biol. Med. 134: 33-37.

26. Miller, R., and R. Phillips. 1969. Separation of cells by velocity sedimentation. J. Cell Physiol. 73: 191-201.

27. Messner, H., J. Till, and E. McCulloch. 1973. Interacting cell populations affecting granulopoietic colony formation by normal and leukemic human marrow cells. Blood. 42: 701-710.

28. Messner, H. J. T., II, and E. McCulloch. 1972. Density distribution of marrow cells from mouse and man. Semin. Hematol. 5: 22-34.

29. Moore, M., W. Williams, and D. Metcalf. 1973. In vitro colony formation by normal and leukemic human hematopoietic cells. Interaction between colony forming and colony stimulating cells. J. Natl. Cancer Inst. 50: 591602 .

30. Shadduck, R., and D. Metcalf. 1975. Preparation and neutralization characteristics of an anti-csa antibody. J. Cell Physiol. 86: 247-252.

31. Heber-Katz, E., and R. Click. 1972. Immune response in vitro. V. Role of Mercaptoethanol in the mixed leukocyte reaction. Cell. Immunol. 5: 410-418.

32. Parker, J., and D. Metcalf. 1974. Production of colonystimulating factor in mitogen stimulated lymphocyte cultures. J. Immunol. 112: 502-510.

33. Knudtzon, S. 1974. Growth stimulation of normal human bone marrow cells in agar culture by human serum. Scand. J. Haematol. 12: 298-306.

34. Alberts, D., and D. Golde. 1975. DNA synthesis in multiple myeloma cells following cell cycle non-specific chemotherapy. Cancer Res. 34: 2911-2914.

35. Salmon, S. E. 1975. Expansion of the growth fraction in multiple myeloma with alkylating agents. Blood. 45: 119-129.

36. Drewinko, B., B. Brown, D. Humphrey, and R. Alexanian. 1974. Effect of chemotherapy on the labelling index of myeloma cells. Cancer. 34: 526-531. 